\title{
MAINSTREAMING REALISM PARADIGM IN HANDLING ILLEGAL IMMIGRANTS IN MALAYSIA
}

\author{
Surwandono, Fitriani Nengsi, Ali Maksum ${ }^{1}$ \\ Universitas Muhammadiyah, Yogyakarta
}

\begin{abstract}
:
In the past few decades, the Malaysian government has seen a serious securitization of migration related to the "threat" posed by illegal immigrants. This perception arose due to a flood of illegal immigrants in Malaysia have begun to show a negative impact, given the fact that many of the illegal immigrants are involved in crime and there is a strong perception of threat to Malaysia's national security. This policy is considered effective and it has been proven that the issue of foreign migrants has become a serious discourse in the Malaysian community and government. In this wake, this article explores how the Malaysian government behaves related to securitization in the context of the narrative of the law. This kind of study is still rarely done, although it is critical, since it is basically the real attitude of a country in fighting for its national interests. The article tries to explore of policies implemented by the Malaysian government, especially during Najib Razak administration, in securitizing the issue of illegal immigrants. And it tries to answer the fundamental questions posed by the theory of securitization regarding who the securitization actors are, why, for whom, and what the results are.
\end{abstract}

Keywords: Content Analysis, Illegal Immigrant, Malaysia, Realism, Security

Título en Castellano: Incorporando un paradigma realista en la gestión de la emigración ilegal en Malasia

\section{Resumen:}

En las últimas décadas, el gobierno de Malasia ha implementado políticas de securitización en relación con la "amenaza" que representan los inmigrantes ilegales. Esta percepción apareció cuando la afluencia de personas inmigrantes ilegales empezó a tener un impacto negativo, por ejemplo, al verse estas implicadas en actos delictivos, provocando así una gran percepción de amenaza para la seguridad nacional de Malasia. Se considera que estas políticas son eficaces y se ha demostrado que las personas migrantes extranjeras se han convertido en un asunto clave en el discurso de la población y del gobierno de Malasia. En este contexto, este artículo investiga cómo el gobierno de Malasia se comporta en relación con la securitización en el ámbito legislativo. Este tipo de estudios es todavía escaso a pesar de ser crucial, pues permite esclarecer la actitud real de un país que lucha por sus intereses nacionales., Esta investigación explora el tipo de políticas de seguridad implementadas por el gobierno de Malasia, particularmente durante la administración de Najib Razak, frente a la cuestión de los inmigrantes ilegales. Este estudio busca responder a las cuestiones fundamentales de la teoría de la securitización en cuanto a quiénes son los actores de la securitización, por qué y para quién actúan, y cuáles son los resultados.

Palabras Clave: Análisis de Contenido, Inmigrante Ilegal, Malasia, Realismo, Seguridad

Copyright (C) UNISCI, 2019.

Las opiniones expresadas en estos artículos son propias de sus autores, y no reflejan necesariamente la opinión de UNISCI. The views expressed in these articles are those of the authors, and do not necessarily reflect the views of UNISCI

\footnotetext{
${ }^{1}$ Surwandono is Associate Professor of International Relations as well as Head of Master of International Relations, Universitas Muhammadiyah Yogyakarta, E-mail: <surwandono@umy.ac.id>. Fitriani Nengsi is Research Assistant at the Department of International Relations, Universitas Muhammadiyah Yogyakarta, E-mail: <fitrianinengsi3@gmail.com>. Ali Maksum is Assistant Professor of International Relations, Universitas Muhammadiyah Yogyakarta, E-mail: <ali.maksum@fisipol.umy.ac.id>
}

DOI: http://dx.doi.org/10.31439/UNISCI-82 


\section{Introduction ${ }^{2}$}

According to the Immigration Act 1959/63, illegal immigrant means a person, other than a citizen, who contravenes section 5, 6, 8, 9 or 15 of this Act or regulation 39 of the Immigration Regulations 1963 [F.L.N. 228/1963]. ${ }^{3}$

The excerpt above shows that the Malaysian government already has clear guidelines regarding the handling of foreign migrants. The law was certainly influenced by British occupiers who were very strict. The issuance of a law launched since 1959 shows the level of vigilance and high awareness of the Malaysian government about the potential for disruption due to illegal foreign migrants. Although in that era, foreign migrants in Malaysia were still considerably small, at least they had predicted the dynamics amid various issues, i.e. unfinished borders to the complexity of cultural crossings with neighboring countries such as Indonesia. ${ }^{4}$ Moreover, the phenomenon of globalization has indeed shown its symptoms in the era of the $1950 \mathrm{~s}^{5}$

One of the most serious effects of globalization is the drastic increase in uncontrolled crossborder human movement. One of the triggers is the socio-economic changes in the country. In the next stage, the issue of real migration became a controversial issue between the state elites and the people. Cross-country migration especially has had an impact on the social change of a nation. Migration is also increasingly dynamic, which is basically classified in the form of legal migration and illegal migration. ${ }^{6}$ Foreigners entering the country without proper and legal documents, such as visas and passports are always the main problem. The existence of illegal immigrants is actually in the discourse of many countries in the world.

When compared to other countries in Southeast Asia, Malaysia is a country that faces serious problems related to the number of illegal immigrants entering the country. Malaysia is one of the countries in Southeast Asia that attracts more foreign, legal and illegal workers, compared to its neighboring countries. The entry of immigrants, both legal and illegal, is not a new phenomenon in Malaysia. The development of agriculture and mining facilitated the entry of Chinese and Indian workers starting in 1890, and reached its peak in the 1920s. Between the late 1950s and the early 1960s, the influx of Indonesian migrants to the Malay Peninsula was somewhat welcomed by Kuala Lumpur to maintain the supremacy of the Malays over the balance of the non-Malays. The entry of migrants was further driven by the introduction of the New Economic Policy (NEP) which began in 1971 along with the Second Malaysian Plan (1971-1975), and the economic development achieved through the 1980s. Indonesia, the Philippines, Nepal, Bangladesh, Myanmar, Cambodia and Thailand are the main countries of origin of the immigrants who entered Malaysia. Most of them came to Malaysia seeking jobs and a better life_-including the illegal immigrants. ${ }^{7}$

At the same time, the labor force in Malaysia is not abundant and the prospects for their growth are unclear given the declining population growth. The urbanization growth has caused

\footnotetext{
${ }^{2}$ The authors extend their gratitude to the Ministry of Research, Technology, and Higher Education of the Republic of Indonesia for funding this research and the anonymous reviewers for their useful comments. The views expressed in this article are our own and do not represent the Ministry of Research, Technology, and Higher Education of the Republic of Indonesia

${ }^{3}$ Immigration Act 1959/63, 55E [7]

${ }^{4}$ Maksum, Ali. (2017): Menyingkap Tabir Hubungan Indonesia-Malaysia [The Disclose of Indonesia-Malaysia Relations], Yogyakarta, The Phinisi Press.

5 Jones, Geoffrey. (2005): Multinationals and Global Capitalism: From the Nineteenth to the Twenty-First Century, Oxford, Oxford University Press.

${ }^{6}$ Tajari, A., and Affendi, N.: "Illegal Immigrant and Security Crisis in Sabah (Malaysia)", International Conference on Social Science Research (ICSSR), June 2015, Kuala Lumpur, World Conference.

${ }^{7}$ Kassim, A., and Haji Mat Zin, R.: "Policy on Irregular Migrants in Malaysia: An Analysis of its Implementation and Effectiveness", Philippine Journal of Development, Vol.38, n¹-2 (2011), pp. 85-104.
} 
an acute labor shortage in rural areas and especially in the plantation sector. This is the result of the growth of the middle classes in Malaysia along with the increase in the level of education and welfare. As a consequence, there is a shortage of serious and professional workers, especially in the domestic sector/domestic help and manufacturing industries. Another factor is political instability in the neighboring countries that also triggered massive migration to Malaysia seeking asylum, working either as full-time or casual workers. Finally, the relatively slower economic growth in the neighboring countries, including low wages and high unemployment, also makes Malaysia an attractive labor market destination. ${ }^{8}$

The number of illegal immigrants in Malaysia have gradually increased ${ }^{9}$. However, the number of the illegal immigrant population in Malaysia is very difficult to determine with certainty. Judging from the definition, these people were not registered by the authorities given that their entry and exit data are not recorded. Therefore, the number of illegal immigrants in Malaysia can only be estimated, but not with certainty. The following is a table of estimates of the number of illegal immigrants' populations in Malaysia.

\section{Figure 1. Estimation of Illegal Immigrants in Malaysia}

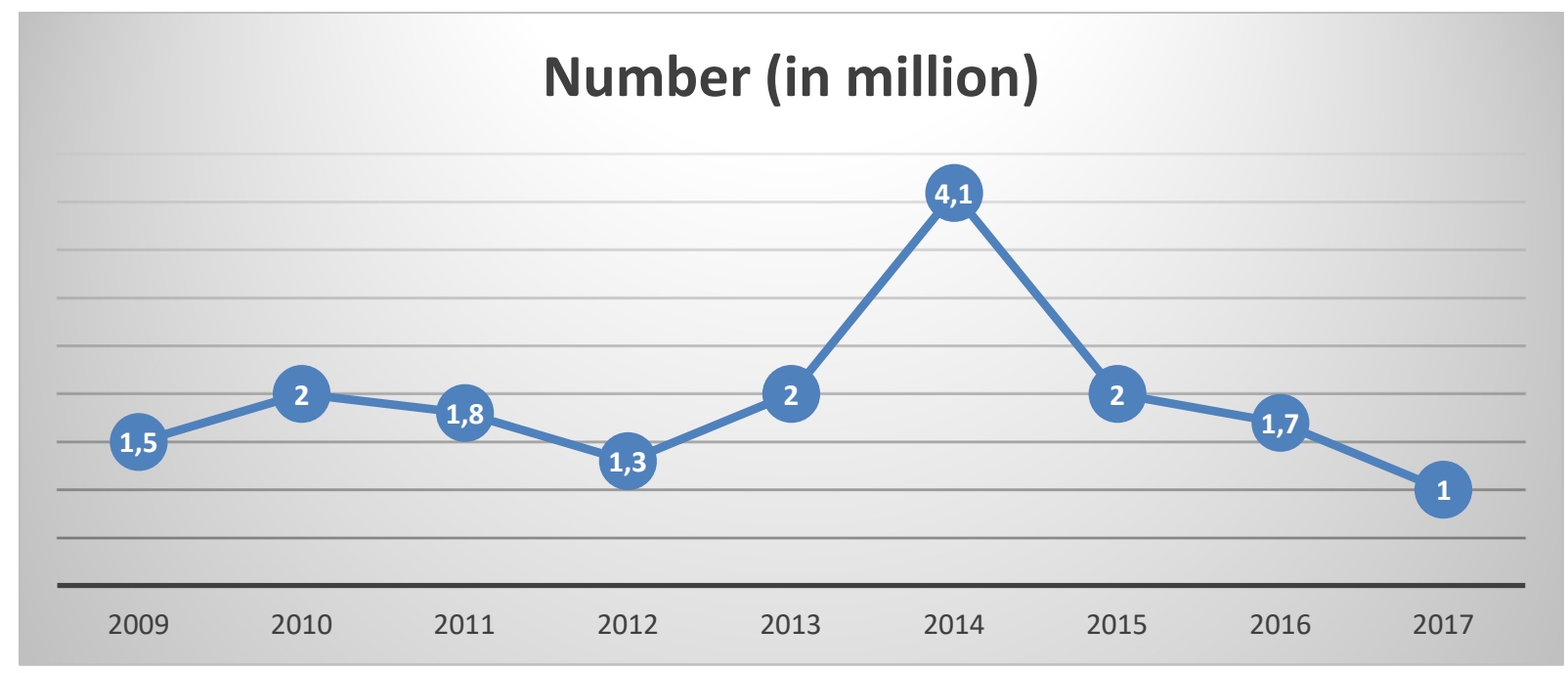

Source: Department of Migration, 2017.

The high number of illegal immigrants in Malaysia has resulted in a dilemma of impacts-both positive and negative. The positive impact of the presence of illegal immigrants in Malaysia is the fulfillment - or even surplus - of the labor force, especially in areas known as 3D (Dirty, Degrading, Disgusting). The 3D sector tends to be in demand because the interest of local workers in this sector is very low. Another advantage gained by Malaysia with the explosion of illegal workers is the massive efficiency, especially in the industrial sector. The reason for this is that hiring illegal workers, even though secretly and violating the law, is considered more profitable. As a result, Malaysia's GDP is increasing, companies are increasingly efficient in reducing production costs, there are increasing employment opportunities in the private and public sectors, and salaries for Malaysian citizens are also increasing. ${ }^{10}$

The negative impact is that the presence of illegal immigrants indirectly creates Malaysia's excessive dependence on foreign workers, both legal and illegal. In addition, the Malaysian economy is always threatened by deflation and declining productivity performance. More

\footnotetext{
${ }^{8}$ Moreno, Muñoz, R., et al. (2015): Malaysia Economic Monitor; Immigrant Labour. Kuala Lumpur, The World Bank.

${ }^{9}$ Jovita, H. D. et al.: "Social capital and disasters: How does social capital shape post-disaster conditions in the Philippines?" Journal of Human Behavior in the Social Environment, Vol. 29, no 4 (2019), pp. 519-534.

${ }^{10}$ Loc, op. cit.
} 
seriously, the flood of illegal foreign workers has a real social and economic impact, increasing the country's fiscal and monetary burden, the threat of high crime, and increasing the potential for transmission of dangerous diseases. ${ }^{11}$

Based on the many negative impacts generated by the presence of illegal immigrants in Malaysia, it can be concluded that the problems created by illegal immigration have become the main discourse in Malaysia. The increasing number of illegal immigrants has forced the Malaysian government to take serious steps to deal with this issue. In order to realize this, the Malaysian government implements a strict migration policy, since illegal immigrants are considered as a potential serious threat to Malaysia's national security. Illegal immigrants who are considered as a non-traditional threat ${ }^{12}$ are regarded by the Malaysian government as a serious threat that requires an immediate and effective policy to "save the country". Therefore, the Malaysian government has implemented a number of policies to suppress and minimize the impact arising especially on Malaysian internal security from the flow of foreign workers.

As an official effort to control the movement of migrant workers, Indonesia and Malaysia signed the Medan Pact on May 12, 1984. The aim of the agreement was to reduce the flow of illegal immigrants and prevent exploitation of workers by tracking the flow of migrants. Furthermore, the Malaysian government's efforts to increase illegal entry controls have been increased since the creation of a task force in 1985. However, the agreement did not produce significant results to curb the number of illegal immigrants in Malaysia. Beginning in the early 1990s, the Malaysian government cracked down illegal immigrants, arresting those who lived without legal status. Operation "Nyah" was introduced in 1992 to strengthen surveillance at the border to prevent the entry of illegal immigrants. Interestingly, after a large-scale operation, the government generally implemented an amnesty program to legalize illegal and undocumented immigrants in order to stay and work in Malaysia. ${ }^{13}$

In addition, there are several deeds and regulations on illegal immigration in Malaysia. These include seven regulations, i.e. the Immigration Act 1959/63 (Act No. 155), Passport Act 1966 (Act. 150), Anti-Trafficking Act and Anti-Migrant Smuggling 2007 (Act No. 670), Immigration Act 1963, Employment Act 1968 (Act No. 796), 1995 Prison Act (Act No. 537) and Immigration Depot Regulations (Administration and Management) 2003. ${ }^{14}$

The above regulations form a basic compendium for handling illegal immigration in Malaysia. It can be said that the implementation of formal legal instruments has not been maximized. However, the Malaysian government's efforts to suppress foreign migrants through a series of repressive policies need to be appreciated and taken as a lesson. Therefore, this study becomes important and needs a thorough examination of what was actually embodied in the policies of the Malaysian government. Certainly, this study also provides a valuable

\footnotetext{
11 Abdul-Rahman, Hamzah. et al.: "Negative impact induced by foreign workers: Evidence in Malaysian construction sector", Habitat International, Vol.36, nº4 (2012), pp. 433-443; Sahimin, Norhidayu. et al.: "Migrant Workers in Malaysia: Current Implications of Sociodemographic and Environmental Characteristics in the Transmission of Intestinal Parasitic Infections" PLoS Neglected Tropical Diseases, Vol.10, n¹1(2016), pp. 1-17. ${ }^{12}$ Srikanth, Divya: "Non-Traditional Security Threats in the 21st Century: A Review", International Journal of Development and Conflict, Vol.4 (2014), pp. 60-68.

${ }^{13}$ See Kassim and Haji Mat Zin, Op.cit.

${ }^{14}$ Choo, C. L. and Mokhtar, K. S.: "Deportation Turn in Malaysia: Expansion, Discourse and Practice", Journal of Population and Social Studies, Vol.25, n² (2017), pp. 147-166; Del Carpio, X., et al: Immigration in Malaysia: Assessment of its Economic Effects, and a Review of the Policy and System, Kuala Lumpur, The World Bank Working Paper, 2013; Ministry of Home Affairs of Malaysia. (2018): Peraturan-Peraturan Imigresen (Pindaan) 2018: Immigration (Amendment) Regulations 2018, at http://www.federalgazette.agc.gov.my/outputp/pub_20180222_P.U.(A)49.pdf ; See Kassim and Haji Mat Zin, op.cit.
} 
recommendation especially for improving Indonesian policies related to the threat that foreign migrants have como to pose.

\section{Conceptual Framework}

The phenomenon of migration as a necessity in the era of globalization is related to the increasingly open opportunities for mobility and support for information technologies and transportation. The Deutsche Gesellschaft für Internationale Zusammenarbeit study shows the migration cycle is related to a number of interrelated phenomena such as climate change policy and security, ${ }^{15}$ which will then affect the migration policy structure. ${ }^{16}$ Migration policy will also affect the remittances phenomena, private sector development, diaspora cooperation and migrant worker management.

\section{Figure 2. Migration Framework17}

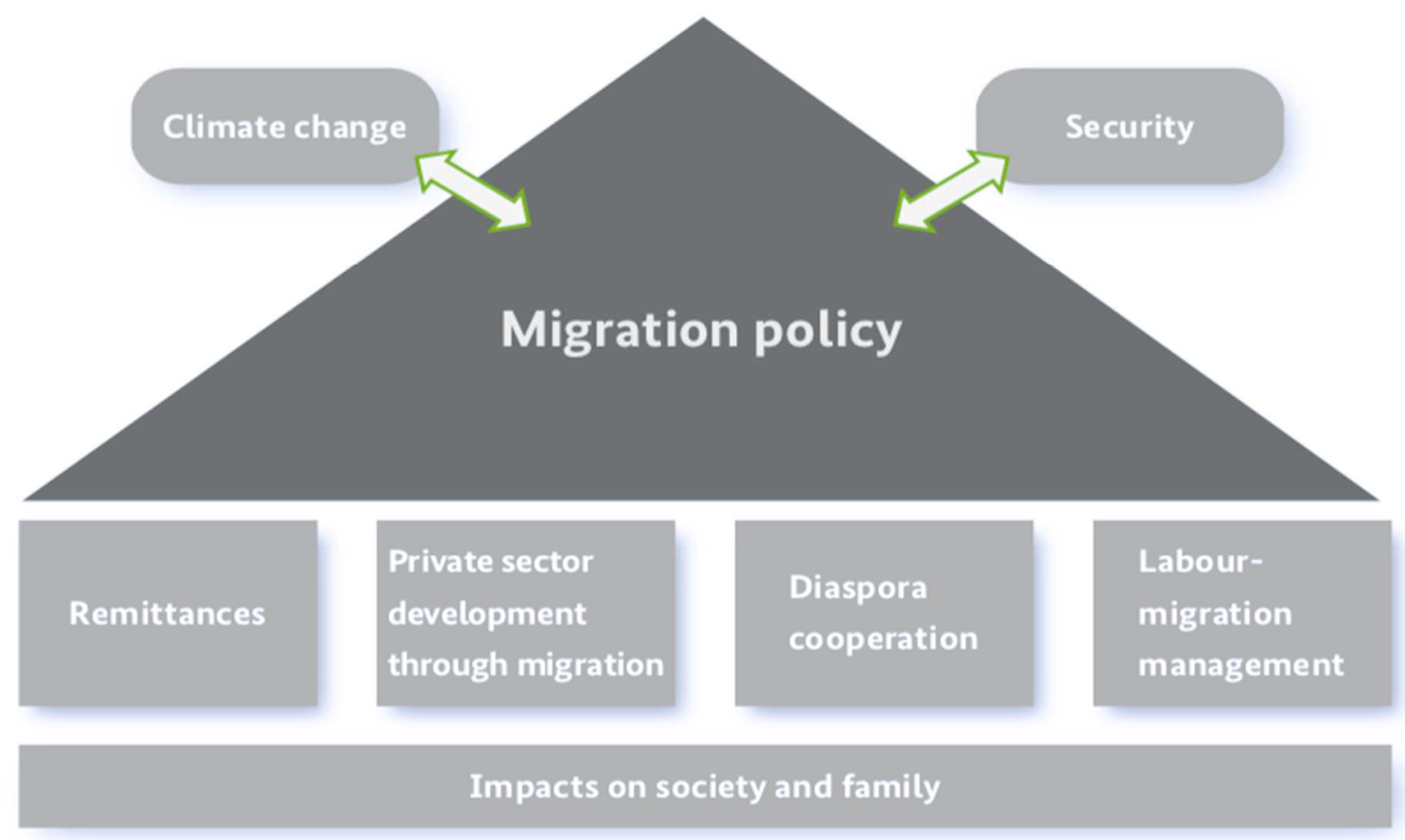

The climate change variable is highly related to other countries and international institutions, regardless of whether or not the state sign and ratifies a number of international agreements. In addition, the security variable is related to the country's perception of the effects of the immigrant flows to the country. At the same time, there are two major approaches that can explain the response of recipient countries to the presence of migrant groups-securitization of migration theory developed by Bourbeau ${ }^{18}$ and the approach that promotes the migration citizenship theory developed by Gibney and Kofman. ${ }^{19}$

The securitization of migration is built from the big assumption that the presence of groups or outside communities is perceived to have a great threat potential that can disrupt a country's

\footnotetext{
${ }^{15}$ Modified from Huysmans, Jef: "The European Union and the Securitization of Migration', Journal of Common Market Studies, Vo. 38, no5 (2000), pp. 751-777. <https://doi.org/10.1111/1468-5965.00263>.

${ }^{16}$ Deutsche Gesellschaft für Internationale Zusammenarbeit, Migration Policy: Migration Policy Guidelines for Practice (Berlin, 2013).

${ }^{17}$ Ibid.,

${ }^{18}$ Bourbeau, Philippe (2014): The Securitization of Migration: A Study of Movement and Order, The Securitization of Migration, London, Routledge. <https://doi.org/10.4324/9780203829349>.

${ }^{19}$ Gibney, M. J.: 'Citizenship and Immigration in Post-War Britain: The Institutional Origins of a Multicultural Nation', Journal of Refugee Studies, Vol.15, n4(2002), pp.425-426 <https://doi.org/10.1093/jrs/15.4.425>.
} 
security status, both in the context of traditional and non-traditional security. ${ }^{20}$ Therefore, migrant groups must be closely and systematically supervised. While the citizenship migration approach is built on the big assumption that migrant groups make a positive contribution to the economic and social development of recipient countries, ${ }^{21}$ and migrant groups must get an incentive to encourage their willing to stay longer in the recipient country through a policy of protection for their human rights. ${ }^{22}$

Migration security approach in the discipline of international relations is strongly influenced by realism which defends that the state has the greatest authority to determine autonomously its political choices to achieve the national interests of a country. ${ }^{23}$ International pressure for guarantying the protection of human rights only becomes admissible if the security of the state is previously ensured. The state tends to be a monolithic decision maker with its own jurisdiction. All decisions on migration will be carried out systematically by the state bureaucracy, from the national to the regional level.

The citizenship approach to migration is strongly influenced by the theory of liberalism where achieving the national interest is largely determined by opening up and expanding the civil liberties of local residents and migrant groups. ${ }^{24}$ International mobility is more or less considered as general phenomenon that per se does not generate a significant security threat. ${ }^{25}$ In order to contribute to the development of the public and private sectors, migrant groups must obtain guarantees of protection from the state ${ }^{26}$ as experienced in the UK in managing the migration issue in post-World War II. Civil groups are the principal actors with a paramount role in the discourse of decision-makers on migration. The performance of the bureaucracy that implements the migration policies has to be supervised by the public as well. Migration governance must prioritize the principles of transparency and equality, respecting international norms.

What about the theory of constructivism in the issue of migration? Constructivism theory is a middle ground approach between social theory based on realism and liberalism, ${ }^{27}$ which then led to the structuration approach of Anthony Giddens. ${ }^{28}$ International relations constructivists, like Alexander Wendt, adopted Giddens's thoughts in their constructivist premise, further developing the concept of identity as a process of social relations between agents ${ }^{29}$ The state becomes one of the agents and agents do not behave autonomously as it happens in the realist approach.

\footnotetext{
${ }^{20}$ Ibid.

${ }^{21}$ Vink, Maarten P. and de Groot, Gerard Rene: 'Citizenship Attribution in Western Europe: International Framework and Domestic Trends', Journal of Ethnic and Migration Studies, Vol.36, n5 (2010), pp. 713-734. <https://doi.org/10.1080/13691831003763914>.

${ }^{22}$ Kofman, Eleonore: 'Citizenship, Migration and the Reassertion of National Identity', Citizenship Studies, Vol.9, no5 (2005), pp. 453-467 <https://doi.org/10.1080/13621020500301221>.

${ }^{23}$ Waltz, Kenneth (1999): International Relations Theory: Realism, Pluralism, Globalism, Boston, M.A., Allyn and Bacon.

${ }^{24}$ Rathbun, Brian C.: 'Is Anybody Not an (International Relations) Liberal?', Security Studies, Vol.9, nº1(2010), pp. 2-25 <https://doi.org/10.1080/09636410903546558>.

${ }^{25}$ Ikenberry, G. John: 'The Liberal International Order and Its Discontents', Millennium: Journal of International Studies, Vol.38, n³(2010),pp. 509-521. <https://doi.org/10.1177/0305829810366477>.

${ }^{26}$ Gibney, op.cit.

${ }^{27}$ Berenskötter, Felix: 'Deep Theorizing in International Relations', European Journal of International Relations,' Vol.24, nº (2018)814-840 <https://doi.org/10.1177/1354066117739096>.

${ }^{28}$ Falkheimer, Jesper: 'Anthony Giddens and Public Relations: A Third Way Perspective', Public Relations Review, Vol.33, n³(2007), pp. 287-93 <https://doi.org/10.1016/j.pubrev.2007.05.008>.

${ }^{29}$ Dunne, Timothy: 'The Social Construction of International Society', European Journal of International Relations, Vol.1, n³(1995), pp. 367-389 pp <https://doi.org/10.1177/1354066195001003003>.
} 
Constructivism views the importance of international norms governing the mobility of people from one country to another, whether in the context of political, social, economic, or disaster mobility. ${ }^{30}$ A study from Peekanen states that the presence of international institutions that establish norms on international migration is an alternative that countries need to consider when formulating migration policies. ${ }^{31}$

Civil society supporting migrant groups needs protection, ${ }^{32}$ and can be able to make a contribution for shaping the international legislation creating new migration rules. ${ }^{33}$ The presence and activities of NGOs concerned with the issue of migration in fact create a process of social relations and build a migration supra-structure agreed upon that can become an international norm. In the view of constructivism, the norm is the most important variable that determines state behavior. ${ }^{34}$ The state actually makes decisions according to the norms that are developed in the international community. ${ }^{35}$ In this context, the ethics of protecting migrant groups has become a political necessity.

In general, the security governance concept departs from the democratic peace theories that emphasize the importance of the norm aspects and the formation of an institution. ${ }^{36}$ In the context of democratic peace, the theory concludes that the more democratic a country is, the security governance will be more secure and national stability c if for example we compare an be achieved. This is due to the fact that in a democratic system, a strong institutional system is created, and all the threats can be overcome with good security governance. Public participation, if runs well and is transparent, becomes an absolute necessity for ensuring the security governance. $^{37}$

Interestingly, comparing, as an example, Malaysia and Indonesia, Malaysia is not recognized as having the full democratic standars that Indonesia has. However, Malaysia has a better security governance, especially in handling illegal immigrants. This fact runs against the democratic peace theory that maintains that the more democratic a country is, the better security governance will have. Therefore, this becomes important for Indonesia, learning from Malaysia how efficient the security governance management can be.

\section{Content Analysis}

To achieve the objectives mentioned above, this study uses the quantitative content analysis to analyze the data or analyze the content of specific messages contained in the formal legal products that are the subject of this research.

\footnotetext{
${ }^{30}$ Peters, Anne: 'How Not to Do Things with International Law', Ethics and International Affairs, Vol.32, no4(2018), pp. 483-491. 〈https://doi.org/10.1017/S0892679418000746>.

${ }^{31}$ Pekkanen, Saadia et al. (2014): "Constructivism and International Relations in Asia," in The Oxford Handbook of the International Relations of Asia, Oxford, Oxford University Press.

${ }^{32}$ Shaw, Timothy M. et.al.: 'Global and/or Regional Development at the Start of the 21st Century? China, India and (South) Africa', Third World Quarterly, Vol.28, $\mathrm{n}^{\circ} 7(2007)$, pp. 1255-1270. <https://doi.org/10.1080/01436590701591804>.

${ }^{33}$ Vincent, R. J. (1992): “The Idea of Rights In International Ethics,” in Nardin, Terry and Mapel, David R. (1992): Traditions of International Ethics, Cambridge, Cambridge University Press, pp.250-269. doi:10.1017/CBO9780511521768.013.

${ }^{34}$ Gismondi, M. (2008): Ethics, Liberalism and Realism in International Relations, London, Routledge. https://doi.org/10.4324/9780203939932

${ }_{35}$ Peters, Anne: "How Not to Do Things with International Law," Ethics \& International Affairs, Vol. 32, nº4(2018), pp. 483-491. doi:10.1017/S0892679418000746

${ }^{36}$ Mello, Patrick A.: "Democratic Peace Theory", in Joseph, Paul I. (2014): The SAGE Encyclopedia of War: Social Science Perspectives, Thousand Oaks, Sage Publication, at https://ssrn.com/abstract=2674255 Oaks, Thousand

${ }^{37}$ Mello, Patrick A. (2014): Democratic Participation and Armed Conflict: Military Involvement in Kosovo, Afghanistan, and Iraq, Basingstoke, Palgrave Macmillan.
} 
Based on the main theories of International Relations, this research tries to perform a comprehensive analysis of a number of laws related to security governance, due to the fact that there are not many content analysis-based studies that use mainstream international relations theory as their guide. Therefore, the authors offer three hypotheses. First, the construction of a policy on handling illegal immigration in Malaysia uses the paradigm of liberalism. Second, the construction of a policy on handling illegal immigration in Malaysia uses the realism paradigm. Third, the construction of a policy on handling of illegal immigration in Malaysia uses the constructivism paradigm

This is a study on political communication which strive to examine the messages included in a number of documents. To get an accurate structure of the orientation of illegal immigrant governance, this article chooses quantitative research methods and content analysis. Quantitative research is used to understand social phenomena by measuring social facts into a numerical distribution. ${ }^{38}$ In the context of content analysis, the social facts are documented in a number of documents. There is a big assumption that documents are social relations processes that are prepared intentionally and systematically. It means reading the real document is the same as reading the social reality itself. ${ }^{39}$

Three fundamental steps are taken to read and transform the document into a social reality.

First, the authors selected documents from the set of documents published. Regarding Malaysia's immigration policy, there are 17 policies at both the central and state levels. This article chooses the policy structure of the central government because it constitutes the legal policy umbrella for the lower level. The selected regulations at Malaysian central government are Immigration Act 1959/63 (Act No. 155), Passport Act 1966 (Act. No. 150), Act of AntiTrafficking in Persons and Anti-Smuggling of Migrants 2007 (Act No. 670), Immigration Act 1963, Employment Act 1968 (Act No. 796), Prison Act 1995 (Act No. 537), and Immigration (Administration and. Management of Immigration Depots) Regulations 2003.

Second, the selection of instruments that can be used to carry out the measurement process of the diction used in the seven Malaysian immigration documents. Five major codes are selected as indicators of realism, liberalism, and constructivism approaches-actors, authority, budgeting, governance, and output. ${ }^{40}$ These five big indicators are later converted and transformed in sub-indicators and subsequently the signs are obtained. This research produced 153 dictions traced in the documents. The tracking results were tabulated from the number of the appearing frequencies. Then, they were compiled graphically, and are used to interpret the structure of the Malaysian immigration policy, whether it's approaching realism, liberalism, or constructivism.

Third, the authors carried out the analysis based on a word cloud application. ${ }^{41}$ This analysis is used to read 153 dictions. Which diction is most widely used, and in which position, whether in the center or on the edge? The font size and location of the diction is reflected in the process of mainstreaming an approach.

\footnotetext{
${ }^{38}$ Kaid, Lynda Lee (2004): Handbook of Political Communication Research, New Jersey, Lawrence Erlbaum Associates.

${ }^{39}$ Dougherty, Deborah: "Book Review: The Content Analysis Guidebook," Organizational Research Methods, Vol.8, n³ (July 2005), pp. 342-344. doi:10.1177/1094428105277417.

${ }^{40}$ Surwandono et al.: "Menakar Pendekatan Keamanan Nasional Melalui Analisis Isi terhadap UU No. 17 Tahun 2011 tentang Intelijen Negara [Measuring National Security Approach Through Content Analysis towards Law no. 17/2011 on National Intelligence]", Jurnal Mandala, Vol.1, nº1 (2018), pp. 19-37.

${ }^{41}$ Barolli, Leonard et al. (2018): Complex, Intelligent, and Software Intensive Systems: Proceedings of the 12th International Conference on Complex, Intelligent, and Software Intensive Systems (CISIS-2018), Berlin, Springer.
} 


\section{Discussions and Results}

To determine the structure of the realist paradigm in the management of illegal immigrants, the article is organized following three major stages.

First, the analysis is focused on the distribution of the use of selected dictions, whether the diction represents realism, liberalism, or constructivism. The analysis focuses on the total number of dictions used in the regulation and is transformed into a percentage.

Second, the analysis is focused on tracing the indicator structure of each paradigm. To provide clear information, a comparison analysis is chosen, comparing all indicators and displaying them in a graphical presentation.

Third, using software, the analysis of major themes was displayed in the form of the font size in the 'word cloud'. The greater a font size appears, the tronger construction process the diction has.

Based on the data analysis of the documents, the realism approach is dominant in the discourse, i.e. actor indicators with a percentage of $96.63 \%$, authority indicators with a percentage of $60.51 \%$, governance indicators with a percentage of $72.84 \%$, and output indicators with a percentage of $56.25 \%$. One indicator is dominant in the liberalism approach, i.e. the budget source indicator with a percentage of $94.02 \%$. However, the results of the content analysis have to be developed further. We still need an average value to determine which approach is the most dominant after all indicators in the policy management of illegal migration are studied. Therefore, the accumulative results of the indicators are needed to determine which one of the three approaches is the most dominant in the practical regulation and policy regarding the handling of illegal immigration in Malaysia. Tables 2 and 3 below shows the accumulative results of all the indicators.

\section{Figure 2. The trend of the IR approach in the security governance of the Malaysian government to deal with illegal immigrants}

\section{Palicy Paradigms}

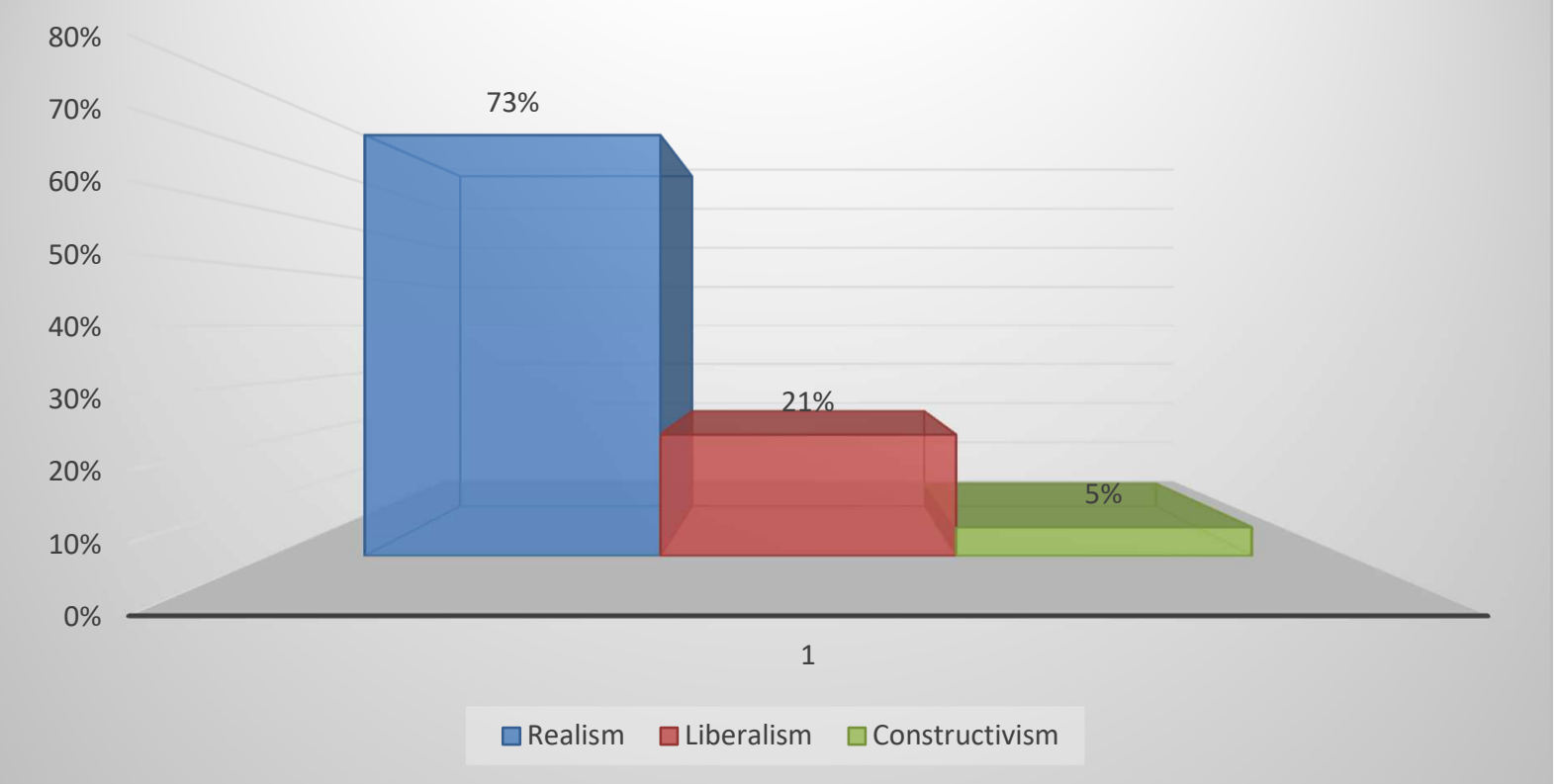

Source: Based on author's content analysis on Malaysian security laws 
Figure 3. Trend of indicators that appear in security governance in Malaysia related to the handling of illegal immigrants

\section{Approach Indicators}

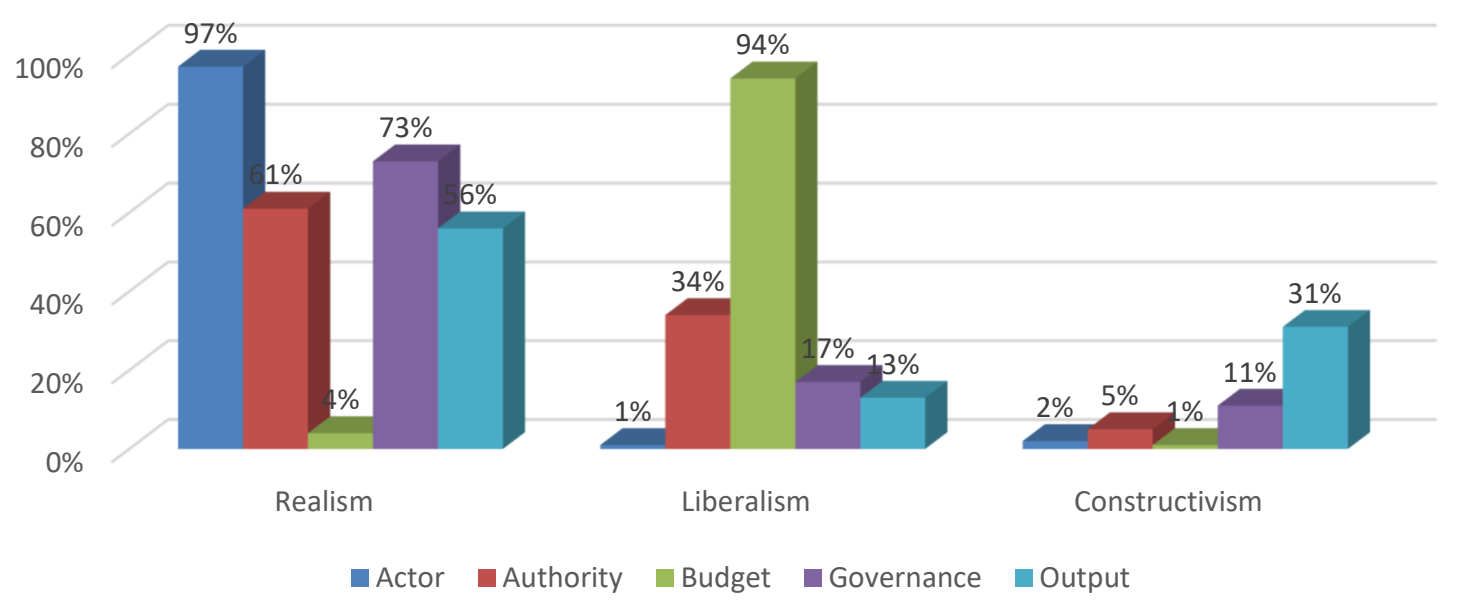

Source: Based on author's content analysis on Malaysian security laws

Based on the results of this table, the approach with the smallest percentage is the constructivism approach $(5.45 \%)$, the approach with the second largest percentage is the liberalism approach (21.29\%), and the approach with the largest percentage is the realism approach (73.24\%). Therefore, based on the conclusion results from the table, the policy construction for dealing with illegal migration in Malaysia uses the realism paradigm.

The paradigm of realism in the policy of handling illegal immigration in Malaysia can be seen in the form of coercive forms of punishment that are widely used. The most commonly forms of punishment are fines, prison sentences or detention, caning, and deportation. ${ }^{42}$ The penalties to parties involved in illegal migration depends on the type of violation. For illegal immigrants, the penalties-imposed amount to a fine of 10,000 RM plus a maximum of 5 years of imprisonment and 6 lashes. In addition, illegal immigrants who are illegally employed are subject to a fine of 10,000 RM-50,000 RM and imprisonment of no more than 12 months, and illegal re-entry is subject to a fine of $10,000 \mathrm{RM}$, a maximum of 5 years of imprisonment and 6 lashes. For the owner or part of the transportation crew carrying illegal immigrants into Malaysia, a fine of 1,000 RM per person is imposed. Business owners and labor recruitment agents who hire illegal immigrants are subject to a fine of 10,000-50,000 RM, a maximum of 12 months of imprisonment per person, and, if they employ more than 5 illegal immigrants, they are sentenced to between 6 months to 5 years imprisonment and 6 lashes. Providers of residence for illegal immigrants are also subject to a fine of 5,000 RM-30,000 RM and a maximum of 12 months in prison and if the crime is repeated, they are subject to a fine of 10,000 RM-60,000 RM and a maximum sentence of 2 years of imprisonment.

Apart from those types of punishment, there are still many other types of penalties described in the relevant regulations. The punishment is not only targeted at illegal immigrants, but at all parties involved in the crime. This shows that the handling of illegal migration is

\footnotetext{
${ }^{42}$ Please see Choo and Mokhtar, Op.cit ; Kanapathy, V.: "Impact of the Economic Crisis on International Migration in Asia a Year After: Country Report for Malaysia”, ILO/SMC Conference on Assessing the Impact the Global Economic Crisis on International Migration in Asia, 2010, Manila, Philippine, Mekong Migration Network; Kudo, Sasagu.: "Securitization of undocumented migrants and the politics of insecurity Malaysia", Procedia Environmental Sciences, Vol.17 (2013), pp. 947-956; Ramayal, G.: “Organised Crime: Governments Initiatives, Laws and Investigation of Human Trafficking In Person and Smuggling of Migrants in Malaysia”, International Conference on Trafficking, 2013, Melaka, World Youth Foundation.
} 
carried out comprehensively and holistically. Not only that, the type of punishment that is coercive and uses coercion as the main system of punishment shows the seriousness and firmness of the Malaysian government in dealing with the issue of illegal migration.

One of the most widely implemented policies is the raid operations for arresting illegal immigrants aimed precisely at the places where violations of the law occur. On September 1, 2013, the Malaysian government launched a national raid operation called Ops 6P Bersepadu (6P Integrated Operations), which was expected to affect to 45,000 businesspeople hiring illegal immigrants and arrest around 400,000 illegal immigrants. This high-level operation involved 135,000 law enforcement officers from various institutions, including the Malaysian AntiCorruption Commission. Operations are carried out in squatter houses, plantations, entertainment outlets, and massage parlors throughout the country. There were 2,278 raids carried out in which 16,800 illegal immigrants and 219 entrepreneurs were arrested during the first phase of the 6P Integrated Ops. In addition to 6P Integrated Operations, starting on July 1, 2017, the Department of Migration launched the Mega Ops (Special Operations) to get rid of illegal immigrants and punish guilty employers. Entrepreneurs and immigrants who fail to submit an E-Card before the deadline of June 30, 2017 are tracked under the national daily operation. From July 1 to July 24, 2018, 1,066 raids were carried out and arrested 14,585 illegal immigrants and 4,576 businesspeople. ${ }^{43}$ After being caught, illegal immigrants in particular will be included in the immigration depot detention center and usually, after that, they go through a judicial process to determine the type of sanction and they will be deported. The scale and duration of the operation and the use of force and pressure as the methodology for its implementation indicate that the raid operation was another coercive policy of the Malaysian government in responding to the issue of illegal migration.

The implementation of illegal immigration policies in Malaysia is almost entirely within the power of the state, in this case, the Malaysian federal government. The three main actors in the Malaysian immigration system are the Cabinet Committee for Foreign Workers and Illegal Immigrants (JKKPA/PATI), the Ministry of Human Resources (MOHR), and the Ministry of Home Affairs (MOHA). The three government institutions are at the federal level. For the states of Sabah and Sarawak, specifically for the policy of handling illegal immigrants, the implementation is carried out by officers and officials who are part of the three government institutions. $^{44}$

The Immigration Law 1959/63 - the Act that has become the main foundation in the immigration policy in Malaysia — has been amended five times to reduce the number and impact of illegal immigrants that continue to increase. The amendment in 1971 introduced penalties not only for illegal immigrants, but also for those involved in illegal immigration, i.e. from workplace companies, recruitment agencies, transportation owners, smuggling agents, and corrupt officers and officials. The amendments in 1997 and 2002 were then put in place to give more severe penalties to illegal immigrants and all parties involved. In addition to this form of punishment, guarding the area and raids are tactics previously implemented in the coercive handling of illegal migration. ${ }^{45}$

The following is a display in world cloud, related to the trend of words that appear in the main law of the Malaysian government, the Immigration Act 1959, such as the words Malaysia, act, state, immigration, officer and director appear. Therefore, the security governance policy

\footnotetext{
${ }^{43}$ Choo, C. L.: "A Strategy of Attrition through Enforcement: The Unmaking of Irregular Migration in Malaysia”, Journal of Current Southeast Affairs, Vol.36, n² (2017), pp. 101-136.

${ }^{44}$ Moreno, Op.cit.

${ }^{45}$ Please see Kassim and Haji Mat Zin, Op.cit.; Kanapathy, V.: "ILO Asian Regional Programme on Governance of Labour Migration”, Working Paper No.14; Controlling Irregular Migration: The Malaysia Experience, 2008, Thailand, International Labour Organization.
} 
implemented by the Malaysian government, can indeed be said to be considerably dominated by the realism approach, compared to the other two approaches-liberalism and constructivism - in the theory of International Relations. This is as illustrated by using word cloud.

\section{Figure 4. Word cloud from the Immigration Act 1959}

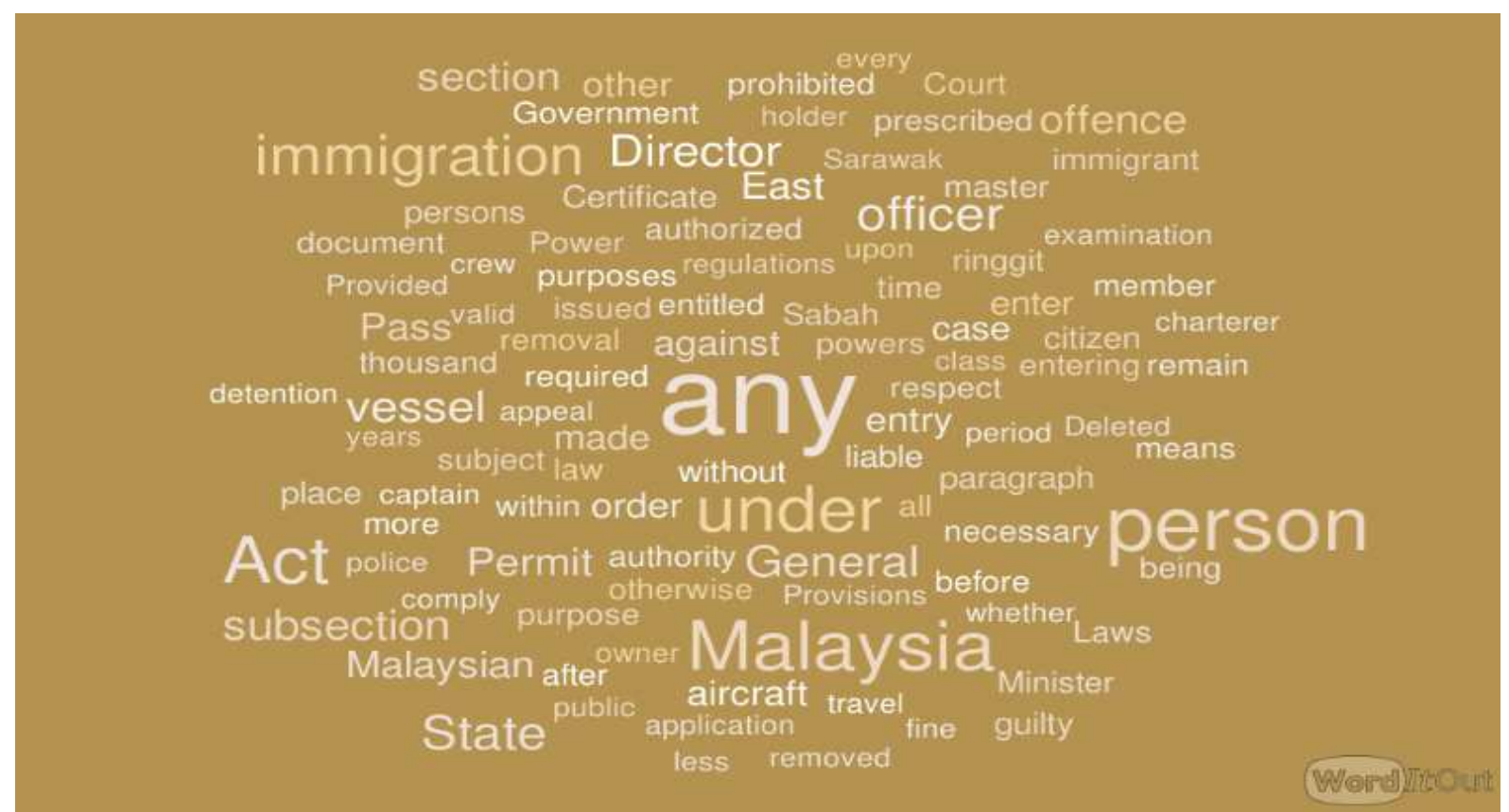

Source: based on author's word cloud analysis on Malaysian Immigration Act 1959

The results of the amendments to the seven regulations show the increasingly coercive forms of punishment and the strong supervision by the state in implementing illegal immigration policies. The realism paradigm then becomes the direction used in the government to apply the contents of the regulation on handling illegal migration.

\section{Conclusion}

The the realism paradigm in handling illegal immigration in Malaysia can be seen in the use of the arrests process, coercive punishment and the full power of the state, especially from the Malaysian federal government, in the policies implemented. In addition, the amendments to some of the analyzed regulations were the result of demands for more stringent and coercive forms of punishment against illegal immigrants in Malaysia. Apart from the various controversies and consequences resulting from the implementation of the policies, the Malaysian government is considered successful in properly controlling and managing illegal immigrants.

However, although it is recognized that the challenge of illegal immigration cannot be overcome by a hundred percent, at least it must be recognized that the problem of illegal immigration does not disturb the security of Malaysia. This means that the Malaysian government's security governance is fairly effective even though the applied approach is realist. 


\section{Bibliography}

“Act 150: Passports Act 1966. Retrieved from Official Portal of Attorney's General Chamber of Malaysia" Parliament of Malaysia, 2006, at

http://www.agc.gov.my/agcportal/uploads/files/Publications/LOM/EN/Act\%20150.pdf

"Act 155: Immigration Act 1959/63, Official Portal of Attorney's General Chamber of Malaysia" Parliament of Malaysia, 2006, at

http://www.agc.gov.my/agcportal/uploads/files/Publications/LOM/EN/Act\%20155.pdf

“Act 537: Prison Act 1995. Retrieved from Official Portal of Attorney's General Chamber of Malaysia”, Parliament of Malaysia, 2009, at

http://www.agc.gov.my/agcportal/uploads/files/Publications/LOM/EN/Act\%20537.pdf

“Act 670: Anti-Trafficking in Persons and Anti-Smuggling of Migrants Act 2007”, Official Portal of Attorney's General Chamber of Malaysia, Parliament of Malaysia 2009, at http://www.agc.gov.my/agcportal/uploads/files/Publications/LOM/EN/Act\%20670.pdf

"Parliament of Malaysia: Act 1474: Prison (Amendment) Act 2015." Official Portal of Attorney's General Chamber of Malaysia, 2015, at

http://www.federalgazette.agc.gov.my/outputaktap/20150105_A1474_BI_Act\%20A1474-

BI.pdf

"Parliament of Malaysia: Act 796: Employment (Restriction) Act 1968." Official Portal of Attorney's General Chamber of Malaysia, 2017, at

http://www.federalgazette.agc.gov.my/outputaktap/aktaBI_20171115_Act796-

Employment(Restriction)Act1968.pdf

"Parliament of Malaysia: ACT A1500: Anti-Trafficking in Persons and Anti-Smuggling of Migrants (Amendment) Act 2015." Official Portal of Attorney General's Chamber of Malaysia, 2015, at

http://www.federalgazette.agc.gov.my/outputaktap/20151102_1500_BI_WJW005504\%20BI. pdf

Abdul-Rahman, Hamzah. et al.: "Negative impact induced by foreign workers: Evidence in Malaysian construction sector”, Habitat International, Vol.36, nº4 (2012), pp. 433-443;

Barolli, Leonard. et.al. (2018): Complex, Intelligent, and Software Intensive Systems: Proceedings of the 12th International Conference on Complex, Intelligent, and Software Intensive Systems (CISIS-2018), Berlin, Springer.

Berenskötter, Felix: 'Deep Theorizing in International Relations', European Journal of International Relations,' Vol.24, no 4 (2018), pp. 814-840, at https://doi.org/10.1177/1354066117739096.

Bourbeau, Philippe (2014): The Securitization of Migration: A Study of Movement and Order, The Securitization of Migration, London, Routledge, at https://doi.org/10.4324/9780203829349.

Choo, C. L. and Mokhtar, K. S.: "Deportation Turn in Malaysia: Expansion, Discourse and Practice", Journal of Population and Social Studies, Vol.25, nº 2 (2017), pp. 147-166;

Choo, C. L.: "A Strategy of Attrition through Enforcement: The Unmaking of Irregular Migration in Malaysia", Journal of Current Southeast Affairs, Vol.36, $\mathrm{n}^{\circ} 2$ (2017), pp. 101-136.

Del Carpio, X. et al: Immigration in Malaysia: Assessment of its Economic Effects, and a Review of the Policy and System, Kuala Lumpur, The World Bank Working Paper, 2013; 
Deutsche Gesellschaft für Internationale Zusammenarbeit, Migration Policy: Migration Policy Guidelines for Practice, Berlin, 2013.

Dougherty, Deborah: "Book Review: The Content Analysis Guidebook," Organizational Research Methods, Vol.8, n 3 (July 2005), pp. 342-344, at https://journals.sagepub.com/doi/10.1177/1094428105277417

Dunne, Timothy: 'The Social Construction of International Society', European Journal of International Relations, Vol.1, no3(1995), pp. 367-389, at https://doi.org/10.1177/1354066195001003003.

Falkheimer, Jesper: ‘Anthony Giddens and Public Relations: A Third Way Perspective', Public Relations Review, Vol.33, no3 (2007), pp. 287-93, at https://doi.org/10.1016/j.pubrev.2007.05.008>.

Gibney, M. J.: 'Citizenship and Immigration in Post-War Britain: The Institutional Origins of a Multicultural Nation', Journal of Refugee Studies, Vol.15, n 4(2002), pp.425-426, at https://doi.org/10.1093/jrs/15.4.425.

Gismondi, M. (2008): Ethics, Liberalism and Realism in International Relations, London, Routledg, at https://doi.org/10.4324/9780203939932

Huysmans, Jef: "The European Union and the Securitization of Migration', Journal of Common Market Studies, Vo. 38, no5 (2000), pp. 751-777, at https://doi.org/10.1111/1468-5965.00263.

Ikenberry, G. John: 'The Liberal International Order and Its Discontents', Millennium: Journal of International Studies, Vol.38, no3(2010), pp. 509-521, at

https://doi.org/10.1177/0305829810366477.

Immigration Act 1959/63, 55E [7]

Jones, Geoffrey. (2005): Multinationals and Global Capitalism: From the Nineteenth to the Twenty-First Century, Oxford, Oxford University Press.

Jovita, H. D. et.al.: "Social capital and disasters: How does social capital shape post-disaster conditions in the Philippines?" Journal of Human Behavior in the Social Environment, Vol. 29, $\mathrm{n}^{\mathrm{o}} 4$ (2019), pp. 519-534.

Kaid, Lynda Lee (2004): Handbook of Political Communication Research, New Jersey, Lawrence Erlbaum Associates.

Kanapathy, V.: "ILO Asian Regional Programme on Governance of Labour Migration", Working Paper $\mathrm{n}^{\mathrm{o}}$ 14; Controlling Irregular Migration: The Malaysia Experience, 2008, Thailand, International Labour Organization.

Kanapathy, V.: "Impact of the Economic Crisis on International Migration in Asia a Year After: Country Report for Malaysia", ILO/SMC Conference on Assessing the Impact the Global Economic Crisis on International Migration in Asia, 2010, Manila, Philippine, Mekong Migration Network;

Kassim, A., and Haji Mat Zin, R.: "Policy on Irregular Migrants in Malaysia: An Analysis of its Implementation and Effectiveness", Philippine Journal of Development, Vol. 38, $\mathrm{n}^{\mathrm{o}}$ 1-2 (2011), pp. 85-104.

Kofman, Eleonore: 'Citizenship, Migration and the Reassertion of National Identity', Citizenship Studies, Vol.9, no 5 (2005), pp. 453-467, at https://doi.org/10.1080/13621020500301221. 
Krippendorff, K. (2019): Content Analysis: An Introduction to Its Methodology, Thousand Oaks, Sage Publication.

Kudo, Sasagu.: "Securitization of undocumented migrants and the politics of insecurity Malaysia”, Procedia Environmental Sciences, Vol.17 (2013), pp. 947-956 at https://www.sciencedirect.com/science/article/pii/S1878029613001151

Maksum, Ali. (2017): Menyingkap Tabir Hubungan Indonesia-Malaysia [The Disclose of Indonesia-Malaysia Relations], Yogyakarta, The Phinisi Press.

Mello, Patrick A. (2014): Democratic Participation and Armed Conflict: Military Involvement in Kosovo, Afghanistan, and Iraq, Basingstoke, Palgrave Macmillan.

Mello, Patrick A.: "Democratic Peace Theory", in Joseph, Paul I.(2014): The SAGE Encyclopedia of War: Social Science Perspectives, Thousand Oaks, Sage Publication,.at https://ssrn.com/abstract=2674255

Ministry of Home Affairs of Malaysia. (2018): Peraturan-Peraturan Imigresen (Pindaan) 2018: Immigration (Amendment) Regulations 2018, at

http://www.federalgazette.agc.gov.my/outputp/pub_20180222_P.U.(A)49.pdf (accessed 14 October 2018).

Moreno, Muñoz, R., et al. (2015): Malaysia Economic Monitor; Immigrant Labour. Kuala Lumpur, The World Bank.

Pekkanen, Saadia et.al. (2014): "Constructivism and International Relations in Asia," in The Oxford Handbook of the International Relations of Asia, Oxford, Oxford University Press.

Peters, Anne: 'How Not to Do Things with International Law', Ethics and International Affairs, Vol.32, no4 (2018), pp. 483-491. at https://doi.org/10.1017/S0892679418000746.

Ramayal, G.: "Organised Crime: Governments Initiatives, Laws and Investigation of Human Trafficking in Persons and Smuggling of Migrants in Malaysia", International Conference on Trafficking, 2013, Melaka, World Youth Foundation.

Rathbun, Brian C.: 'Is Anybody Not an (International Relations) Liberal?', Security Studies, Vol.9, ${ }^{\circ} 1$ (2010), pp. 2-25 at https://doi.org/10.1080/09636410903546558.

Sahimin, Norhidayu et al.: "Migrant Workers in Malaysia: Current Implications of Sociodemographic and Environmental Characteristics in the Transmission of Intestinal Parasitic Infections" PLoS Neglected Tropical Diseases, Vol.10, n¹1(2016), pp. 1-17.

Shaw, Timothy M. et.al.: 'Global and/or Regional Development at the Start of the 21st Century? China, India and (South) Africa', Third World Quarterly, Vol.28, $\mathrm{n}^{\circ} 7(2007)$, pp. 1255-1270. at https://doi.org/10.1080/01436590701591804.

Srikanth, Divya: "Non-Traditional Security Threats in the 21st Century: A Review", International Journal of Development and Conflict, Vol.4 (2014), pp. 60-68.

Surwandono et al.: "Menakar Pendekatan Keamanan Nasional Melalui Analisis Isi Terhadap UU No. 17 Tahun 2011 Tentang Intelijen Negara [Measuring National Security Approach Through Content Analysis Toward Law no. 17/2011 on National Intelligence]", Jurnal Mandala, Vol.1, nº1(2018), pp. 19-37.

Tajari, A., and Affendi, N.: "Illegal Immigrant and Security Crisis in Sabah (Malaysia)", International Conference on Social Science Research (ICSSR), June 2015, Kuala Lumpur, World Conference. 
Vincent, R. J.: "The Idea of Rights In International Ethics," in Nardin, Terry and Mapel, David R. (1992): Traditions of International Ethics, Cambridge, Cambridge University Press, pp.250269. doi:10.1017/CBO9780511521768.013.

Vink, Maarten P. and de Groot, Gerard Rene: 'Citizenship Attribution in Western Europe: International Framework and Domestic Trends', Journal of Ethnic and Migration Studies, Vol.36, n⿳5 (2010), pp. 713-734. at https://doi.org/10.1080/13691831003763914.

Waltz, Kenneth (1999): International Relations Theory: Realism, Pluralism, Globalism, Boston, M.A., Allyn and Bacon. 